一論文—

（日本化学会誌，1993，（4）， p. 355～362）

(C) 1993 The Chemical Society of Japan

\title{
有機ケイ素触媒存在下での亜臭素酸ナトリウムを用いた 環状エーテル類の酸化
}

\author{
(1992 年 11 月 2 日受理)
}

宮原行治・影山俊文*・守谷 治†

\begin{abstract}
クロロトリメチルシラン $\left(\mathrm{Me}_{8} \mathrm{SiCl}\right)$ を触媒として，亜莫素酸ナトリウム $\left(\mathrm{NaBrO}_{2}\right)$ による環状エー テル類の酸化を行ったところ, 相当するラクトン体が生成することを見いたした。とくに，この酸化系 はテトラヒドロフラン (THF) からの r-ブチロラクトンの合成に有効であった。また，環状ビニルエ 一テルに本酸化系を適用すると好収率でブロモ置換のラクトン体が生成した。同様にして，六〜七員環 の環状エーテル類の酸化を行ったところ，ラクトン体は得られるものの低収率であった。しかし，この ような場合には，酸を助触媒として用いると収率は向上した。

一方, $\mathrm{NaBrO}_{2}$ の活性化に効果があり，いくつかの酸化反応に利用してきたクロロトリブチルスタン ナン $\left(\mathrm{Bu}_{8} \mathrm{SnCl}\right)$ や硫酸銅 $\left(\mathrm{CuSO}_{4}\right)$ 触媒では, ラクトン環形成反応への有効性が認められなかった。 さらに，助触媒として使用する酸について検討したところ，酢酸などの有機酸はラクトン体生成への促 進効果を示さなかった。

$\mathrm{Me}_{8} \mathrm{SiCl}$ と塩酸を触媒とし， $\mathrm{NaBrO}_{2}$ を用いる本酸化反応は，温和な条件下，環状エーテルからラ クトンへのワンポット反応による簡便な変換法として利用できた。
\end{abstract}

\section{1 㒂 言}

著者らはこれまでに亜臭素酸ナトリウム $\left(\mathrm{NaBrO}_{2}\right)$ を用いた 酸化反応の合成化学に淤ける適用性について検討してきた。これ らの研究汇通してて，酸性条件下，あるいは微量の金属イオンの存 在で $\mathrm{NaBrO}_{2}$ が活性化され種々の反応において, 温和な酸化剂と

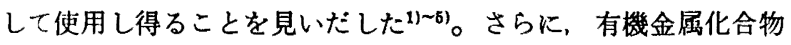
を触媒とした酸化系は，アルデヒトオキシムからのニトリルオキ シトの生成 ${ }^{6}$ や，芳香族多環式炭化水素化合物との反応 ${ }^{7}+\varepsilon$ ，選 択的な酸化反応沉有用であることを報告した。

本報では，このよらな有機金属触媒を用いた酸化系の合成化学 に抢ける応用の一つとして, 環状エーテルからのラクトン生成反 応について検討した。

関東学院大学工学部工業化学科，236 横浜市金沢区六浦 町

1 防衙大学校化学教室, 239 横須賀市走水

1) T. Kageyama, S. Kawahara, K. Kitamura, Y. Ueno, M. Okawara, Chem. Lett., 1983, 1097.

2) T. Kageyama, Y. Tobito, A. Katoh, Y. Ueno, M. Okawara, ibid., 1983, 1481.

3) T. Kageyama, Y. Ueno, M. Okawara, Synthesis, 1983, 815

4）影山俊文, 日化, 1972, 1064.

5）影山俊文，今村秀夫，上野芳男，大河原 信，日化，1983, 999.

6) O. Moriya, H. Nakamura, T. Kageyama, Y. Urata, Tetrahedron Lett., 1989, 3987.

7) 谷田部 純, 森安健二, 守谷 治, 影山俊文, 日化, 1992, 729 .
ラクトン類は天然物の基本骨格あるい性合成中間体として重要 であり，多くの合成法が報告8されている。これらの中で，環状 エーテルからのラクトン合成については，クロム酸9や酸化ルテ

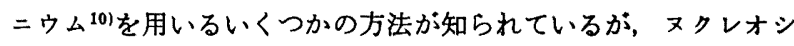
ドの合成 ${ }^{11)}$ を関連して，より簡便な手法の開発に與味か持たれ る。そこで，環状エーテルからのラクトン環合成を目的とした $\mathrm{NaBrO}_{2}$ による酸化反応での種々の有機金属触蝶の有効性, なら びに触媒量の酸を併用した酸化系の効果について以下に述べる。

\section{2 実験}

\section{1 試 菓}

$\mathrm{NaBrO}_{2}$ 昍本シリカ工業(株) $\mathrm{NaBrO}_{3} \cdot 3 \mathrm{H}_{2} \mathrm{O}\left(\mathrm{NaBrO}_{2}\right.$ ； $\left.70.4 \%, \mathrm{H}_{2} \mathrm{O} ; 28.6 \%, \mathrm{NaBrO}_{3} ; 0.7 \%, \mathrm{NaOH} ; 0.3 \%\right)$ をその まま使用した。なお，この純度の分析は既報の方法121従った。 また，実験に使用したその他の試薬值は，いずれも市眅特級品を 使用した。

8) J.F.Wolfe, M. A. Ogliaruso, "The Chemistry of Acid Derivatives"; S. Patai, Ed.: Wiley : New York (1979) Part 2, Chapter 19.

9) V.A.Slavinskaya, S. Hillers, D. Kreile, R. A. Zhuk, D. Apse, A. Strautina, Chem. Abstr., 85, $46001 \mathrm{j}$ (1976).

10) D. M. Simonovic, A. Rao, S. C. Bhattacharyya, Tetrahedron, 19, 1061(1963); S. G. Patneke, S. C. Bhattacharyya, ibid., 23, 919(1963).

11）川上 浩, 惠畑 隆, 松下 有合化, 50, 535(1992).

12）影山俊文，吉田幸夫，杉崎俊夫，日化，1978，1695. 
Table 1 Oxidation of THF by the use of $\mathrm{NaBrO}_{2}$ with organometallic catalyst (Method A)

\begin{tabular}{cccccccc} 
Catalyst & $\mathrm{Me}_{3} \mathrm{SiCl}$ & $\mathrm{Me}_{3} \mathrm{SiOTf}$ & $\mathrm{Me}_{3} \mathrm{SiI}$ & ${ }^{t} \mathrm{Bu}(\mathrm{Ph})_{2} \mathrm{SiCl}$ & $\mathrm{Bu}_{3} \mathrm{SnCl}$ & $\mathrm{Bu}_{2} \mathrm{SnCl}_{2}$ & $\mathrm{CuSO}_{4}$ \\
\hline $\begin{array}{c}\text { Yield of } \\
\text { lactone }(\%)\end{array}$ & 56 & 38 & 16 & 0 & 18 & 12 & 4
\end{tabular}

2.2 有機金属触媒存在下での $\mathrm{NaBrO}_{2}$ による酸化反応 (Method A)

例として，テトラヒドロフラン (THF) の酸化反応について述 ベる。

THF $0.5 \mathrm{~g}(6.93 \mathrm{mmol})$ のジクロロメタン $(14 \mathrm{ml})$ 溶液に, 0.1 モル量の $\mathrm{Me}_{3} \mathrm{SiCl} 0.07 \mathrm{~g}(0.64 \mathrm{mmol})$ を加えた。これに, 3 モル量の $\mathrm{NaBrO}_{2} \cdot 3 \mathrm{H}_{2} \mathrm{O} 3.90 \mathrm{~g}(20.65 \mathrm{mmol})$ を溶解した水溶 液 $(20 \mathrm{ml})$ を室温にて, 30 分かけて滴下し, さらに 3 時間反応 を続けた。その後, この混合物に塩化ナトリウムを飽和するまで 加え、ジクロロメタンにて抽出した。ジクロロメタン溶液は硫酸 マグネシウムにて乵燥後, 溶媒を除去し, 残留物をシリカゲルカ ラムクロマトグラフィー（クロロホルム）で処理して $\gamma$-ブチロラ クトン $0.34 \mathrm{~g}(57 \%)$ を得た。生成物は, IR および ${ }^{1} \mathrm{H}-\mathrm{NMR}$ スペクトルを，別途合成品と比較することにより同定した（図式 1 )。

同様にして, 表 1 および表 2 に示した各酸化反応を行った。 使用した赤外分光光度計は日本分光株式会社製 $\mathrm{A}-3$ 型, 核磁 気共鳴装置は日本電子株式会社製 JEOL-FX 90 Q であった。

種々のラクトン類の物性值を以下に示す。

rーブチロラクトン

IR (neat) : 3000,1760 (CO), 1460, 1420, 1380, 1240, 1160, $1035,990,925,870 \mathrm{~cm}^{-1}$

${ }^{1} \mathrm{H}-\mathrm{NMR}\left(\mathrm{CDCl}_{3}\right) \delta: 2.05 \sim 2.45(\mathrm{~m}, 4 \mathrm{H}), 4.28(\mathrm{t}, J=6$ $\mathrm{Hz}, 2 \mathrm{H}$ )

rーパレロラクトン

IR (neat) : 3000, 1750 (CO), 1440,1360, 1150, 1100, 1050, $1000,940 \mathrm{~cm}^{-1}$

${ }^{1} \mathrm{H}-\mathrm{NMR}\left(\mathrm{CDCl}_{3}\right) \delta: 1.35(\mathrm{~d}, J=3.5 \mathrm{~Hz}, 3 \mathrm{H}), 1.55 \sim 2.60$ $(\mathrm{m}, 4 \mathrm{H}), 4.45 \sim 4.75(\mathrm{~m}, 1 \mathrm{H})$

$\boldsymbol{\delta}$ 一バレロラクトン

IR (neat) : 2950, $1730(\mathrm{CO}), 1445,1400,1370,1260,1160$, 1070, $930 \mathrm{~cm}^{-1}$

${ }^{1} \mathrm{H}-\mathrm{NMR}\left(\mathrm{CDCl}_{3}\right) \delta: 1.55 \sim 2.05(\mathrm{~m}, 4 \mathrm{H}), 2.35 \sim 2.65(\mathrm{~m}$, $2 \mathrm{H})$, 4.27 ( $\mathrm{t}, J=7.5 \mathrm{~Hz}, 2 \mathrm{H})$

$\delta$-カプロラクトン

IR (neat) : 2950, 1740 (CO), 1450,1385, 1240, 1195, 1130, 1080, $1050 \mathrm{~cm}^{-1}$

${ }^{1} \mathrm{H}-\mathrm{NMR}\left(\mathrm{CDCl}_{3}\right) \delta: 1.25(\mathrm{~d}, J=4.0 \mathrm{~Hz}, 3 \mathrm{H}), 1.35 \sim 2.05$ $(\mathrm{m}, 4 \mathrm{H}), 3.85 \sim 4.15(\mathrm{~m}, 2 \mathrm{H}), 5.70(\mathrm{t}, J=4.5 \mathrm{~Hz}, 1 \mathrm{H})$

๕ーカプロラクトン

IR (neat) : 2950, 1730 (CO), 1440,1395, 1350, 1330, 1295, $1255,1170,1090,1060,1015 \mathrm{~cm}^{-1}$

${ }^{1} \mathrm{H}-\mathrm{NMR}\left(\mathrm{CDCl}_{3}\right) \delta: 1.25 \sim 1.78(\mathrm{~m}, 6 \mathrm{H}), 2.35(\mathrm{p}, J=$ $7.0 \mathrm{~Hz}, 2 \mathrm{H}), 4.05(\mathrm{t}, J=7.0 \mathrm{~Hz}, 2 \mathrm{H})$

$\alpha$-ブロモー $\gamma$-ブチロラクトン

IR (neat) : 2900, 1700 (CO), 1460,1420,1380,1160, 1035, $990,870 \mathrm{~cm}^{-1}$

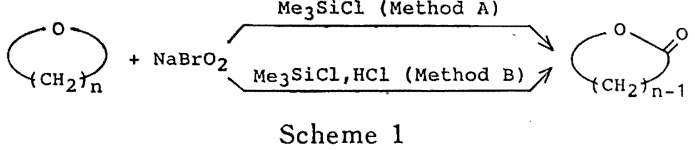

Table 2 Reaction condition and the product yield in oxidation of THF (Method A)

\begin{tabular}{ccccc} 
Run & Solvent & $\begin{array}{c}\text { Ratio of } \\
\text { solvent/ } \\
\text { THF } \\
(\mathrm{m} l / \mathrm{mmol})\end{array}$ & $\begin{array}{c}\text { Ratio of } \\
\mathrm{NaBrO}_{2} / \\
\text { THF } \\
(\mathrm{mol} / \mathrm{mol})\end{array}$ & $\begin{array}{c}\text { Yield of } \\
\text { lactone } \\
(\%)\end{array}$ \\
\hline 1 & $\begin{array}{c}\text { Dichloro- } \\
\text { methane }\end{array}$ & $2 / 1$ & $1 / 1$ & 52 \\
2 & $\prime \prime$ & $2 / 1$ & $3 / 1$ & 56 \\
3 & $\prime \prime$ & $2 / 1$ & $5 / 1$ & 56 \\
4 & $\prime \prime$ & $0 / 1$ & $3 / 1$ & trace $^{a)}$ \\
5 & $\prime \prime$ & $1 / 1$ & $3 / 1$ & 56 \\
6 & $\prime \prime$ & $6 / 1$ & $3 / 1$ & 14 \\
7 & Benzene & $2 / 1$ & $3 / 1$ & 52 \\
8 & Acetone & $2 / 1$ & $3 / 1$ & 10 \\
9 & Ethyl & $2 / 1$ & $3 / 1$ & 15
\end{tabular}

a) The formation of the lactone was detected by ${ }^{1} \mathrm{H}-$ NMR analysis.

${ }^{1} \mathrm{H}-\mathrm{NMR}\left(\mathrm{CDCl}_{3}\right) \delta: 2.00 \sim 2.78(\mathrm{~m}, 3 \mathrm{H}), 4.3(\mathrm{~d}, \quad J=$ 8. $0 \mathrm{~Hz}, 2 \mathrm{H}$ )

$\alpha$-ブロモ- $\delta$-バレロラクトン

IR (neat) : 2950, 1740 (CO), 1440,1405, 1345, 1305, 1250, 1165, 1090, 980, 955, $935 \mathrm{~cm}^{-1}$

${ }^{1} \mathrm{H}-\mathrm{NMR}\left(\mathrm{CDCl}_{3}\right) \delta: 1.75 \sim 2.60(\mathrm{~m}, 5 \mathrm{H}), 4.55(\mathrm{~d}, J=$ $8.5 \mathrm{~Hz}, 2 \mathrm{H}$ )

\section{3 酸を助触媒として用いた系での $\mathrm{NaBrO}_{2}$ による酸化反応} (Method B)

2.1 で述べたよらに調整した環状エーテル 0.1 モル量の $\mathrm{Me}_{3}$. $\mathrm{SiCl}$ とのジクロロメタン溶液に，さらに 0.1 モル量の酸（濃榼 酸の場合は $0.03 \mathrm{~g}$ )を加えて反応を行った。得られた反応液は, シクロロメタンにて抽出した後, 2.1 と同様に処理して生成物を 単離した（図式 1 )。

\section{3 結果および考察}

有機金属化合物存在下での, $\mathrm{NaBrO}_{2}$ による酸化系について は, $\mathrm{Bu}_{3} \mathrm{SnCl}$ を用いた合成について報告6),ててきたが，これら の結果から，本反応系がヒドロキシル基の酸化に有効であること が確認された。また，この酸化系を $1, \omega$-ジオールに適用すると， ラクトンへの変換が可能となる ${ }^{13)}$ 。一方, 環状エーテルからのラ クトン合成も，開環反応を経由して生じた $1, \omega$-ジオールの酸化 により達成できると予想された。したがって，有機金属触媒を含

13）中村英樹，小家 識，守谷 治，影山俊文，日本化学会第 59春季年会講演予稿集, p.1713 (1990) 
む本酸化系の開環反応への寄与が可能ならば，ラクトンへの酸化 がワンポット反応で行えると考え検討した。

3.1 環状エーテルのラクトン化における種々の有機金属触媒 の効果

環状エーテルとしてテトラヒドロフランを用い, 種々の有機金 属你媒を用いた酸化系の有效性を比較した。

結果を表 1 に示したが，これまでに用いてきた有機スズ化合物 および銅イオンの存在下では, THF からラクトンへの酸化はほ とんど進行しなかった。しかし， $\mathrm{Me}_{3} \mathrm{SiCl}$ あるいはトリメチルシ リルトリフルオロメタンスルホナート $\left(\mathrm{Me}_{3} \mathrm{SiOTf}\right)$ では, $58 \%$ および $38 \%$ の収率で，それぞれ $\gamma$-ブチロラクトンを与皇た。こ の結果から，有機スズ化合物に比較し，より Lewis 酸性の高い 有機ケイ素化合物が本反応において有効であることが示された。 また, 先に述べたように, 有機スズ触媒でもアルコール類の酸化 は可能であったことから，これらの有機ケイ素化合物が環状エー テルの開環反応の段階に寄与していることが，推测される。

有機ケイ素化合物でも，かさ高い置換基を持つ $t$-ブチル(ク口 ロ) ジフェニルシラン $\left({ }^{t} \mathrm{Bu}(\mathrm{Ph})_{2} \mathrm{SiCl}\right)$ ではラクトンの生成が認 められなかった。これは, 立体障害により， $\mathrm{NaBrO}_{2}$ との反応が 妨げられだか, あるいはテトラヒドロフランの開環に寄与でき なかったためと思われる。

\section{$3.2 \mathrm{Me}_{3} \mathrm{SiCl}$ 触媒存在下でのテトラヒドロフランの酸化}

3.1 で述べた結果から $\mathrm{Me}_{3} \mathrm{SiCl}$ の存在下でラクトンの生成が 認められたので, 次に酸化剤である $\mathrm{NaBrO}_{2}$ の基質に対するモル 比や溶媒量を変え, 反応に与える影響について検討した。この結 果を表 2 に示す。

THF に対し, $\mathrm{NaBrO}_{2}$ を 1 〜 倍モル量の籁囲で変化させ反 応を行ったが大きな差異は認められず，過剩量使用してもラクト ンの収率は 56\% にとどまった（Run 1〜3)。次に, ラクトン化 反応が主として有機層で進行すると予想し, 有機溶媒量を THF $1 \mathrm{mmol}$ に対して $0 \sim 6 \mathrm{ml}$ まで変化させた。無溶媒の条件下では ほとんど目的とするラクトンは得られず (Run 4), 反応溶液から は高渄点成分の存在が認められた。この成分の精製および同定は 行っていないが, IR スペクトルからはェステル結合の存在が認 められた。したがって, 本例では, THF の開環後, 分子間での 酸化反応が分子内での反応に優先して進行したものと推測され る。また，高希釈条件下でも収率の低下が認められた (Run 6)。 なお, $\mathrm{Me}_{3} \mathrm{SiCl}$ 触媒の使用量に関しては, 0.1 モル量以上でも収 率の大幅な增加は観察されなかった。

有機溶媒としては, ジクロロメタン以外ではベンゼン中でも同 様の結果が得られた（Run 7)。しかし, 酢酸エチルやアセトン中 では，大幅な収率の低下が確認された（Run 8,9)。この原因は明 らかではないが， $\mathrm{NaBrO}_{2}$ の相互作用により促進されたためと思 われる。

\section{3 助触媒として酸を併用したテトラヒドロフランの酸化}

本反応は, 環状エーテルの開環を経由すると予想されるため, 開環の効率がラクトン収率の向上につながると考えて酸を助触媒 とする反応を検討した。

結果を表 3 に示したが，触媒量の塩酸のみを用いた反応でも $72 \%$ の収率でラクトン体が得られ， $\mathrm{Me}_{3} \mathrm{SiCl}$ 触媒の例上りも高 い収率を示した（表 4 Run 3)。しかし， $\mathrm{Me}_{3} \mathrm{SiCl}$ と塩酸とを共 存させた系では収率が $88 \%$ と大幅に向上した。さらに，酢酸な
Table 3 Oxidation of THF in the presence of $\mathrm{Me}_{3} \mathrm{SiCl}$ and acid (Method B)

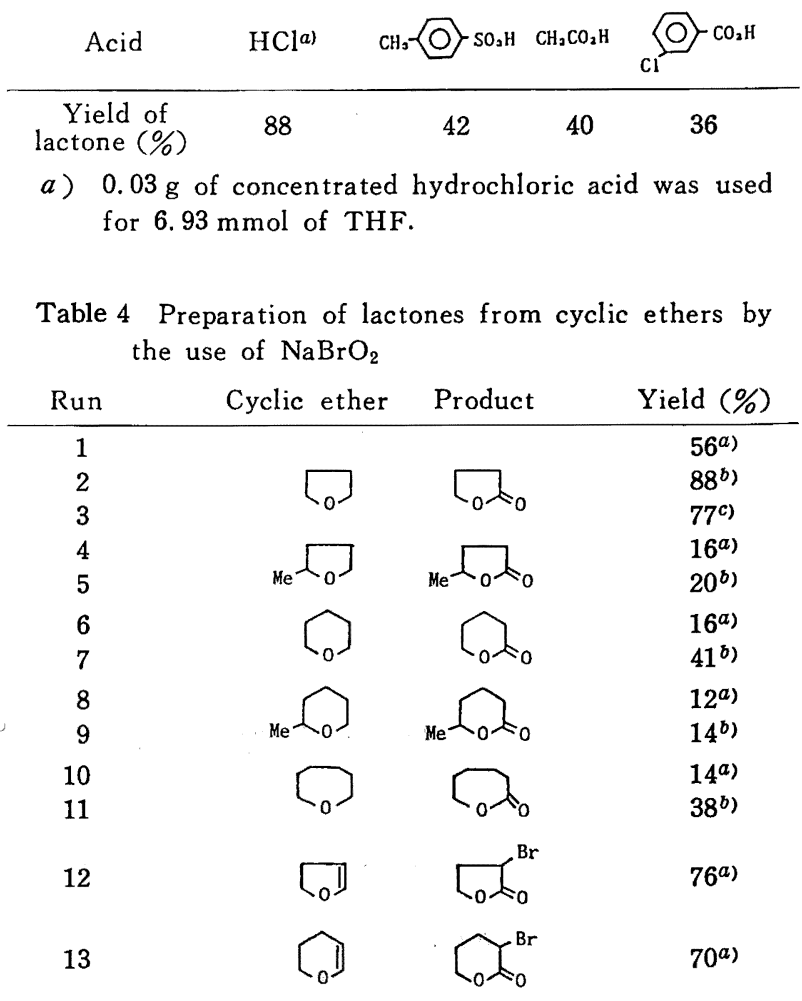

a) Method A was used for the reactions.

b) Method B was used for the reactions.

c) The reaction was carried out in the presence of hydrochloric acid without $\mathrm{Me}_{3} \mathrm{SiCl}$ in Method B.

どの有機酸共存下での反応も行ったが，逆に収率の低下が認めら れた。

$1, \omega$-ジオール類の酸化から酢酸の存在下でラクトン体が高収 率で得られる1 ことを考慮にいれると，本反応において酢酸では 収率が向上せず，塩酸が有効であった事実は，開環時の効率が収 率に大きな影響を扣よぼすものと考えられる。同時に, これらの 結果は，本反応が環状ェーテルの開環によるジオール型中間体を 経由して進行するといった反応機構を示唆している。

\section{4 種々の環状エーテルからのラクトン合成}

3.3 に扎いて述べたように, $\mathrm{Me}_{3} \mathrm{SiCl}$ とともに塩酸を共存させ た酸化系において，ラクトン化が効率的に進行することが確認さ れたので, 本反応系の有効性を調べる目的で種々の環状ェーテル 類の酸化を試みた。

表 4 に示したよらに, 六員環のテトラヒドロピランからは $41 \%$ の収率で (Run7)，また，オキセパンでは $38 \%$ の収率で目的と するラクトン類がそれぞれ得られた（Run 11)。いずれも THF の場合に比校し, 収率は低下した。これは, 環員数の増加による 環の安定化が開環の効率を低下させることに起因すると思われ る。

第二級アルコールを含むジオールの酢酸系に怙ける酸化はラク トン体の生成が困難であることをすでに報告" した。しかし，本 反応系を，開環後に第二級アルコールの生成をともならと予想さ れるメチル置換の環状エーテル類に適用したところラクトン体が 
得られた。2-メチルテトラヒドロフラン（Run 5) および 2-メチ ルテトラヒドロピラン（Run 9）の例に見られるように，対応す るラクトンが 14〜20\% の低収率ながら生成した。

環状ビニルェーテル類の酸化を行ったところ，高収率でブロモ 㯰換のラクトンが得られた。本反応では，塩酸触媒の相乘效果は 認められず, $\mathrm{Me}_{3} \mathrm{SiCl}$ 触媒のみで反応は效率的に進行し, 2,3-ジ ヒドロフランからは対応するブロモラクトン体が $76 \%$ の収率で (Run 12)，また 2,3-ジヒドロピランからは，70\% の収率でブロ モラクトン体が生成した（Run 13）。これらの結果は，本基質で は開環をともなわずに酸化反応が行われたと考えられ，既報2 酢酸を用いた系における通常のアルケン類の酸化と同様の反応機 構でブロモラクトン体が生成したと思われる。

\section{4 結 論}

有機金属触媒の存在下での $\mathrm{NaBrO}_{2}$ による環状エーテル類か
らのラクトン合成では，八ロゲン化有機スズ化合物よりも Lewis 酸性の強い、ロゲン化有機ケイ素化合物のほらが有効であった。 この結果は，本反応が環状エーテル開環反応をともない進行する ことを示唆している。実際, 開環反応に奇与すると考えられる程 酸を触媒量加えることにより，ラクトン体の収率が向上した。ま た, $\mathrm{Me}_{3} \mathrm{SiCl}$ と塩酸の存在下では，第二級アルュールを経由する と思われる 2-位にメチル基を持つ環状エーテル類からのラクト ン合成も低収率ながら可能であった。

以上, $\mathrm{Me}_{3} \mathrm{SiCl}$ 触媒を用いた $\mathrm{NaBrO}_{2}$ の酸化系では, 助触媒と して少量の酸を加えると, 温和な条件下, 環状エーテルからワン ポット反応でラクトンへ容易に変換された。さらに, ビニルェー テル型の炭素-炭素不飽和結合を有する環状化合物では $\mathrm{Me}_{3} \mathrm{SiCl}$ 触媒のみで, ブロモ置換ラクトン類の合成法として応用できるこ とが示された。

\title{
Oxidation of Cyclic Ethers with Sodium Bromite in the Presence of Organoslicon Catalyst
}

\author{
Kouji Miyabara, Toshifumi Kageyama* and Osamu Moriya ${ }^{\dagger}$ \\ Department of Industrial Chemistry, Faculty of Engineering, Kanto Gakuin \\ University; Mutsuura, Kanazawa-ku, Yokohama-shi 236 Japan \\ $\uparrow$ Department of Chemistry, The National Defense Academy; Hashirimizu, \\ Yokosuka-shi 239 Japan
}

Oxidation of cyclic ethers with sodium bromite $\left(\mathrm{NaBrO}_{2}\right)$ in the presence of a catalytic amount of chlorotrimethylsilane $\left(\mathrm{Me}_{3} \mathrm{SiCl}\right)$ afforded coresponding lactones. The oxidizing system was shown to be useful for the preparation of $\gamma$-butyrolactone from tetrahydrofuran (THF). Further, cyclic vinyl ethers were also oxidized readily and gave bromo substituted lactones in good yields. The oxidations of 6 and 7 membered cyclic eyhers to the lactones proceeded, but with less satisfactory results. In such cases, the use of hydrochloric acid as a co-catalyst led to an increase in the yields.

On the other hand, tributylchlorostannane $\left(\mathrm{Bu}_{3} \mathrm{SnCl}\right)$ and copper(II) sulfate, which presented a facile technuque for the activation of $\mathrm{NaBrO}_{2}$ as an oxidizing agent, were not effective in those reactions. As to the co-catalyst, the organic acids such as acetic, $p$-toluenesulfonic, and $m$-chlorobenzoic acid did not enhance the formation of lactones from THF.

The oxidation reaction employing a catalytic amount of $\mathrm{Me}_{3} \mathrm{SiCl}$ and hydrochloric acid with $\mathrm{NaBrO}_{2}$ was demonstrated to be usable as a convenient procedure for the one-pot transformation of cyclic ethers to lactones under Imild conditions. 